\title{
Peran Kepolisian Dalam Sistem Peradilan Pidana Terpadu Terhadap Penanggulangan Tindak Pidana Perjudian
}

\author{
Eddy Santoso ${ }^{*}$, Sri Endah Wahyuningsih ${ }^{* *}$, Umar Ma'ruf ${ }^{* * *}$
}

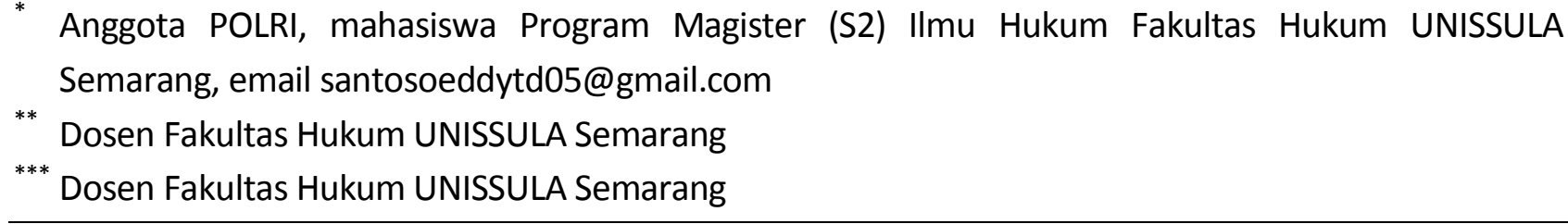

\begin{abstract}
Abstrak
Saat ini, perjudian sudah dalam tahap menghawatirkan. Perkembangan perjudian semakin cepat dan bervariasi, meskipun tindak pidana perjudian merupakan kegiatan terlarang dan dikenakan sanksi, namun tindak pidana ini sulit untuk diberantas. Berkaitan dengan mental masyarakat untuk mengejar materi dengan cara cepat dan mudah, sehingga masyarakat memilih perjudian sebagai alternatif mendapatkan materi dengan cepat. Penanggulangan tindak pidana perjudian harus dilakukan dengan usaha represif dan preventif. Keduanya harus berjalan seimbang. Perjudian dianggap suatu yang lumprah dalam masyarakat sehinga perlu dilakukan penyuluhan dan diperlukan efek jera bagi pelaku perjudian serta diperlukan efek takut untuk melakukan perjudian bagi mereka yang belum melakukan. Dalam sistem peradilan pidana Kepolisian adalah sebagai gatekeepers,sehingga memiliki peran sentral dalam penanggulangan perjudian. Sistem peradilan pidana dimulai dari Kepolisian, sehingga diperlukan usaha preventif dan represif untuk menanggulangi tindak pidana perjudian, karenakepolisian merupakan pihak yang dipercaya oleh masyrakat, sesuai dengan tugas dan fungsinya, maka pihak kepolisian harus mampu memberikan rasa aman dan perlindungan yang tepat bagi masyarakat.
\end{abstract}

Kata Kunci : Perjudian, Polisi, Sistem Peradilan Pidana

\section{Abstract}

Currently, gambling is already in an alarming stage. Gambling developments accelerate and vary, although gambling is illegal and sanctioned, but this crime is difficult to eradicate. Relating to the mental community to pursue the material in a quick and easy way, so that people choose gambling as an alternative to get the material quickly. Penanggulangan gambling crime must be done with repressive and preventive efforts. Both must walk balanced. Gambling is considered a lumprah in the community so it needs to be done counseling and deterrent effect required for the perpetrators of gambling and fear effects required to do gambling for those who have not done. In the criminal justice system the Police is as gatekeepers, so it has a central role in the handling of gambling. The criminal justice system begins with the Police, so it is necessary to prevent and repressive efforts to overcome gambling crime, because police is a party trusted by society, in accordance with its duties and functions, the police should be able to provide a sense of security and appropriate protection for the 
community.

Keywords: Gambling, Police, Criminal Justice System

\section{PENDAHULUAN}

Perjudian merupakan suatu perbuatan yang bertentangan dengan norma agama, kesusilaan, moral, maupun hukum, serta sangat membahayakan bagi kehidupan masyarakat, bangsa dan negara. Berbagai macam bentuk perjudian dewasa ini sering dilakukan oleh masyarakat yang berada disekitar kita baik dilakukan dengan cara sembunyi-sembunyi dan ataupun dilakukan dengan cara terangterangan. Hal ini dikarenakan masyarakat kita sudah menganggap judi itu merupakan hal yang sudah biasa. Ditinjau dari perspektif hukum perjudian ini merupakan salah satu tindak pidana (delict) yang sangat meresahkan pada masyarakat. ${ }^{1}$ Encyclopedia Britanica mencatat bahwa perjudian ditemukan sejak zaman primitif, misalnya suku bushmen di Afrika Selatan, Aborigin di Australia, dan Indian di Amerika, dimana mereka telah mengenal permainan dadu. ${ }^{2}$

Ada beberapa masalah yang timbul akibat perjudian ini adalah bahwa beberapa orang akan menjadi ketagihan, mereka tidak dapat berhenti berjudi dan akhirnya kehilangan banyak uang dan harta. Jadi, jelaslah bahwa judi itu selain merugikan diri sendiri, juga dapat merugikan masyarakat karena selain meracuni jiwa seseorang, juga dapat meracuni perekonomian masyarakat secara luas. Selain rugi uang, mental dan kesehatan juga dapat mendorong para pemain judi menjadi seorang yang pemalas, dan pada akhirnya akan sangat mudah berbuat kriminal seperti mencuri, korupsi, dan bahkan membunuh. ${ }^{3}$ Berdasarkan akibat ataupun pengaruh buruk yang ditimbulkan oleh perjudian, maka banyak negara melarang perjudian dengan memberikan sanksi keras. Perjudian disebut kejahatan dan merupakan tindak kriminal yang menjadi kewajiban semua pihak untuk ikut serta menanggulangi dan memberantas sampai ke tingkat yang paling tinggi. Karena pada dasarnya telah ada peraturan perundang-undangan yang melarang perjudian yakni KUHPidana.

Tidak berdayanya KUH Pidana dalam memberantas perjudian menjadi latar belakang lahirnya Undang-Undang No. 7 Tahun 1974. Undang-Undang ini lahir pada masa orde baru yang merupakan alternatif untuk mengatasi masalah tindak pidana perjudian. Undang-Undang ini jelas menyatakan bahwa ancaman hukuman dalam KUHP untuk perjudian tidak sesuai lagi sehingga perlu diperberat. Bahkan, pasal pelanggaran judi dijadikan kejahatan dan hukumannya dinaikkan dari satu bulan menjadi empat tahun (pasal 542 ayat 1), serta dari tiga bulan menjadi enam tahun (pasal 542 ayat 2). Meski ancaman hukuman diperberat dan delik diubah (dari pelanggaran menjadi kejahatan), tapi masalah masyarakat yakni perjudian ini tidak tertanggulangi. Disinilah peran Kepolisian sebagai salah satu subsistem dalam sisem peradilan pidana menjadi penting. Polisi Sejauh ini daiam teori telah diakui bahwa kedudukan subsistem kepolisian adalah sebagai gatekeepers atau penjaga pintu gerbang dari sistem peradilanpidana. ${ }^{4}$

\footnotetext{
1 http://darpawan.wordpress.com/2009/12/14/menemukan-keadilan-dalam-penjatuhan-pidana/ diakses tgl 31 Januari 2018

Anton Tabah, 1991, Menatap Dengan Mata Hati Polisi Indonesia, PT Gramedia Pustaka Utama, Jakarta, hlm. 182. Ibid.

John Baldwin dan A.Keith Bottomley(ed).1978.CriminalJustice; Selected Readings.MartinRobertson. London. Him. 35.
} 


\section{PEMBAHASAN}

Perjudian bukanlah hal baru atau suatu bentuk permainan baru bagi masyarakat Indonesia karena permainan judi sebenarnya sudah ada sejak dulu dan berkembang secara subur sejalan dengan perkembangan jaman. Perjudian merupakan salah satu penyakit masyarakat yang dalam sejarah dari generasi ke generasi ternyata tidak mudah untuk diberantas. Pengertian penyakit masyarakat adalah segenap tingkah laku manusia yang dianggap tidak sesuai dengan norma - norma yang ada di dalam masyarakat dan adat istiadat atau tidak terintegrasi dengan tingkah laku umum. ${ }^{5}$ Adapun bentuk dan jenis judi yang ada saat ini adalah sebagai berikut :

1. Roulet yaitu jenis perjudian dengan cara mempertaruhkan uang pada salah satu 36 angka dan 2 angka tambahan (jumlah 38 angka), bila tebakannya jitu maka hadiahnya 36 kali uang taruhannya.

2. Black Jack atau selikutan yaitu seorang bandar melayani beberapa penjudi, bila kartu sang bandar yang paling tinggi jumlah angkanya maka semua penjudi kehilangan taruhannya, dan sebaliknya bila bandar mendapatkan kartu yang paling rendah, dia harus membayar permainan judi itu. Tetapi pada umumnya bandar kalah terhadap satu atau dua orang pemain saja.

3. Lotre buntut nalo yaitu mengambil 2 angka terakhir dari nomer nalo, pemasang taruhan harus menebak salah satu dari angka 0-99 jika pasangannya mengena, ia akan dibayar 65 kali uang taruhannya.

4. Tekpo yaitu permainan dengan kartu domino, barang siapa mendapatkan sejumlah angka terbesar, dialah pemenangnya. Peserta terbatas dan menggunakan taruhan kecil, umumnya tekpo dilakukan pada perayaan perkawinan, khitanan dan untuk mengisi waktu.

5. Dadu atau glodog yaitu perjudian dengan menggunakan alat dadu. Caranya menebak sejumlah lingkaran yang ada dibagian atas dadu, bila tebakannya sesuai dengan sejumlah lingkaran yang ada di bagian atas dadu maka dinyatakan menang.

6. Dokding yaitu permainan dengan dadu yang mukanya diberi gambar-gambar binatang, kemudian pemain memasang pada kolom gambar binatang dari kertas yang digelar diatas tanah. Dadunya kemudian di kopyok atau dilempar keatas.

7. Adu dara yaitu 2 merpati yang dilepaskan pada suatu tempat yang telah disepakati, kemudian merpati yang datang lebih awal dinyatakan menang.

8. Oke' adalah dengan menempelkan 2 uang logam dilempar keatas, apabila jatuhnya uang logam tersebut dengan gambar burung maka dinyatakan mati dan apabila gambarnya rupiah maka dinyatakan hidup.

9. Sambung ayam yaitu 2 ayam jantan yang diadu kemudian petaruh memihak kepada salah satu dari kedua ayam tersebut, apabila ayam yang dipihaknya menang maka petaruh dinyatakan menang.

10. Togel merupakan bentuk permianan toto gelap yakni bentuk permainan dengan bertaruh uang dengan menebak nomor-nomor yang akan keluar

Dari bermacam jenis perjudian di atas dapat dikategorikan sebagai tindak pidana yang unsurunsur perbuatannya telah memenuhi unsur yang terdapat dalam pasal 303 ayat (3) KUHP yaitu setiap

5 Kartono, Kartini. 2011. Patologi Sosial Jilid 1. Rajagrafindo Persada, Jakarta. HIm, 53 
permainan yang mengandalkan dari untung-untungan dan keterampilan dari para pemainnya dan pasal 303 bis KUHP yang menyatakan bahwa orang yang melakukan perjudian sebagai mata pencahariannya dapat dipidanakan

Penegakan hukum pidana untuk menanggulangi perjudian sebagai perilaku yang menyimpang harus terus dilakukan. Hal ini sangat beralasan karena perjudian merupakan ancaman yang nyata terhadap norma-norma sosial yang dapat menimbulkan ketegangan individual maupun keteganganketegangan sosial. Perjudian merupakan ancaman riil atau potensiil bagi berlangsungnya ketertiban sosial ${ }^{6}$ Apabila ada pelaku tindak pidana perjudian maka orang tersebut akan dipidanakan sebagaimana sistem peradilan pidana yang ada di Indonesia.

Indonesia yang menganut sistem penegakan hukum terpadu (Integrated Criminal Justice System) yang merupakan legal spirit dari KUHAP. Keterpaduan tersebut secara filosofis adalah suatu instrumen untuk mewujudkan tujuan nasional dari bangsa Indonesia yang telah dirumuskan oleh The Founding Father dalam UUD 1945, yaitu melindungi masyarakat (social defence) dalam rangka mencapai kesejahteraan sosial (social welfare). ${ }^{7}$

Sistem peradilan pidana adalah sistem pengendalian kejahatan yang terdiri dari lembagalembaga kepolisian. Kejaksaan, pengadilan dan permasyarakatan terpidana. ${ }^{8}$ Dikemukakan pula bahwa sistem peradilan pidana (criminal justice system) adalah sistem dalam suatu masyarakat untuk menanggulangi kejahatan. ${ }^{9}$ Lapatra mengatakan, "dari sistem peradilan pidana itu ada empat komponen fungsi satu dengan lainnya selalu berhubungan dan berkoordinasi, yang memiliki satu kesatuan persepsi dan tujuan yang sama, yaitu usaha menanggulangi kejahatan. ${ }^{10}$

Komponen sistem peradilan pidana yang lazim diakui, baik dalam pengetahuan mengenai kebijakan kriminal (criminal policy) maupun dalam praktik penegakan hukum, terdiri atas unsur kepolisian, kejaksaan, pengadilan, dan lembaga pemasyarakatan. ${ }^{11}$

Kepolisian merupakan subsistem dalam sistem peradilan pidana yang cukup menentukan keberhasilan dan kerja keseluruhan sistem dalam memberikan pelayanan kepada masyarakat. Hal ini dikarenakan kepolisian merupakan subsistem yang secara langsung berhubungan dengan pelaku tindak pidana dan masyarakat, sehingga tugas dan tanggung jawab kepolisian dapat dikatakan lebih besar daripada subsistem lainnya.

Kepolisian merupakan badan pemerintah yang bertugas memelihara keamanan dan ketertiban umum ( menangkap orang-orang yang melanggar undang-undang) atau dapat pula diartikan sebagai anggota dari badan pemerintahan (pegawai negeri yang bertugas memelihara keamanan dan

\footnotetext{
6 Karolina Sitepu, 2015. Pemberantasan dan Penanggulangan Tindak Pidana Perjudian Togel di Wilayah Hukum Polresta Medan, Jurnal IImiah "RESEARCH SAINS" Vol. 1 No. 1 Januari 2015. Medan.

7 Romli Atmasasmita, 2002. Sistem Peradilan Pidana ; Perspektif Eksistensialisme dan bilisionisme, Rineka Cipta, Bandung, hal 9-10.

8 Mardjono Reksodiputro, 1993. Sistem Peradilan Pidana Indonesia (Melihat Kepada Kejahatan Dan Penegakan Hukum Dalam Batas-Batas Toleransi), Fakultas Hukum Unversitas Indonesia, HIm. 1

9 Romli Atmasasmita, Op.cit., HIm. 15.

10 J.W. Lapatra, 1078. Analyzing the Criminal Justice Systems, Massachusetts: Lexinton Books,, hlm. 86.

11 Ibid. HIm.24
} 
ketertiban umum). ${ }^{12}$ Sebagai salah satu aparatur penegak hukum memperoleh kewenangannya berdasarkan Undang-Undang Nomor 2 Tahun 2002 Tentang Kepolisian Negara Republik Indonesia yang mengatur tentang hak dan kewajiban polisi. Dalam visi penegakan hukum yang profesional polisi dipandang sebagai entry point yang sangat penting untuk sistem peradilan pidana - dalam hal ini polisi sebagai gatekeeper yang mengelola langkah pertama dalam membawa kekuatan hukum pidana untuk membawa pelanggar ke dalam Sistem Peradilan Pidana. ${ }^{13}$

Dalam kaitannya dengan perjudian, setiap orang yang berhubungan dengan sistem peradilan pidana, pertama-tama yang bersangkutan akan berhadapan dengan subsistem kepolisian. Anggota masyarakat yang sadar akan tanggung jawab sosialnya apabila mengetahui adanya perjudian mestinya menyampaikan apa yang diketahuinya itu kepada subsistem kepolisian. Korban yang berhasil melumpuhkan seorang pelaku kejahatan, tidak lantas menghakimi sendiri pelaku perbuatan pidana, tetapi harus menyerahkannya kepada subsistem kepolisian. Akibatnya setiap pembuat delik yang memasuki sistem peradilan pidana, pertama-tama akan diproses dalam subsistem kepolisian.

Dengan demikian, baik anggota masyarakat, korban, maupun pelaku perjudian ketika bersentuhan dengan sistem peradilan pidana, mereka pertama-tama akan berhadapan dengan subsistem kepolisian. Hal ini sesuai dengan design prosedur sistem peradilan pidana yang dirancang dalam Kitab Undang-Undang Hukum Acara Pidana (KUHAP). Apakah seseorang tersebut akan terus bergulir masuk ke dalam sistem peradilan pidana sangat ditentukan oleh komponenkepolisian. Dalam hal ini apakah apakah perbuatan seseorang kemudian menjadia tindak pidana tertentu dan diselesaikan melalui proses penuntutan di pengadilan dan pemidanaan di lembaga pemasyarakatan, sangat bergantung pada pelaksanaan tugas, wewenang dan tanggung jawab Polri sebagai penyelidik dan penyidik.

Penyidikan merupakan tahap awal dari proses penegakan hukum pidana atau bekerjanya mekanisme sistem peradilan pidana (SPP). Penyidikan mempunyai kedudukan dan peranan yang sangat penting dan strategis untuk menentukan berhasil tidaknya proses penegakan hukum pidana selanjutnya. Pelaksanaan penyidikan yang baik akan menentukan keberhasilan Jaksa Penuntut Umum dalam melakukan penuntutan dan selanjutnya memberikan kemudahan bagi hakim untuk menggali/menemukan kebenaran materiil dalam memeriksa dan mengadili di persidangan. ${ }^{14}$

Penyidikan merupakan kegiatan pemeriksaan pendahuluan / awal (vooronderzoek) yang seyogyanya di titik beratkan pada upaya pencarian atau pengumpulan "bukti faktual" penangkapan dan penggeledahan, bahkan jika perlu dapat di ikuti dengan tindakan penahanan terhadap tersangka dan penyitaan terhadap barang atau bahan yang di duga erat kaitannya dengan tindak pidana yang terjadi. ${ }^{15}$ Penyidikan adalah suatu tindak lanjut dari kegiatan penyelidikan dengan adanya persyaratan dan pembatasan yang ketat dalam penggunaan upaya paksa setelah pengumpulan bukti permulaan

\footnotetext{
12 Momo Kelana, 1994, Hukum Kepolisian, PTIK/Gramedia, Jakarta, hal. 17

13 Mohammad Kemal Darmawan dan Mohammad Irvan Oli'i, 2015. Sosiologi Peradilan Pidana, Fakultas IImu Sosial dan Ilmu Politik Universitas Indonesia bekerjasama dengan Yayasan Pustaka Onor Indonesia, Jakarta, hal. 215

14 Zulkarnaen Koto, 2011. Terobosan Hukum dalam Penyederhanaan Proses Peradilan Pidana, Jurnal Studi Kepolisian, STIK, Jakarta, hal 150

${ }^{15}$ Ali Wisnubroto, 2002. Praktek Peradilan Pidana (Proses Persidangan Perkara Pidana), PT. Galaxy Puspa Mega, Jakarta, hal
} 15 
yang cukup guna membuat terang suatu peristiwa yang patut di duga merupakan tindak pidana. ${ }^{16}$ Dalam bahasa Belanda penyidikan disejajarkan dengan pengertian opsporing. Menurut Pinto, menyidik (opsporing) berarti pemeriksaan permulaan oleh pejabat-pejabat yang untuk itu ditunjuk oleh undang-undang segera setelah mereka dengan jalan apapun mendengar kabar yang sekadar beralasan, bahwa ada terjadi sesuatu pelanggaran hukum. ${ }^{17}$

Istilah lain yang dipakai untuk menyebut istilah penyidikan adalah mencari kejahatan dan pelanggaran yang merupakan aksi atau tindakan pertama dari penegak hukum yang diberi wewenang untuk itu, dilakukan setelah diketahuinya akan terjadi atau diduga terjadinya suatu tindak pidana. Penyidikan merupakan tindakan yang dapat dan harus segera dilakukan oleh penyidik jika terjadi atau jika ada persangkaan telah terjadi suatu tindak pidana. Apabila ada persangkaan telah dilakukan kejahatan atau pelanggaran maka harus diusahakan apakah hal tersebut sesuai dengan kenyataan, benarkah telah dilakukan suatu tindak pidana dan jika benar demikian siapakah pelakunya. ${ }^{18}$

Kedudukan kepolisian sebagai gatekeepers dalam sistem peradilan pidana, berhubungan dengan pelaksanaan fungsi represif terhadap penanggulangan perjudian. Hal ini berpangkal tolak dari bagaimana kinerja kepolisian dalam melacak terjadinya perbuatan pidana dalam hal ini perjudian yang menyidik pelakunya. Dalam hal ini ada dua rangkaian pekerjaan yang meskipun sulit untuk dipisahkan, namun harus dapat dibedakan. Pertama, menemukan dan memastikan apakah suatu perbuatan adalah perbuatan pidana dan menemukan orang yang disangka sebagai pelakunya. Kedua, memproses perbuatan pidana dalam hal ini perjudian dan pelakunya, sehingga terdapat cukup alasan untuk meneruskannya kepada subsistem penuntutan. ${ }^{19}$

Bagi polisi, berkenaan dengan fungsi represifnya terhadap kejahatan adalah mengupayakan agar setiap perkara yang diserahkan kepadanya secepat mungkin dapat terungkap. Kecepatan jajaran kepolisian untuk mengungkap suatu perkara secara keseluruhan sangat menentukan kinerja subsistem kepolisian.

Fungsi subsistem kepolisian sebagai pencegah terjadinya kejahatan diharapkan dapat dimainkan lebih luas sesuai dengan adagium mencegah lebih baik dari pada mengobati. Hal senada dikemukakan oleh EH. Glover bahwa, "theprimaryobjectofanofficientpoliceistheprevention of crime; the next that ofdetectiveandpunishmentofoffendersifcrimeis comitted"

Dengan demikian berkenaan dengan kejahatan, subsistem kepolisian sebagai gatekeepers sistem peradilan pidana seyogyanya berfungsi baik preventif maupun refresif, dan fungsi preventif semestinya mendapat perhatian yang. lebih besar. Hal penting yang perlu dicatat adalah, apabila peran pencegahan kejahatan ingin diberiporsi yang lebih besar dalam pelaksanaan fungsi subsistem kepolisian, maka pencegahan kejahatan itu sendiri harus dijadikan tujuan utama dari sistem peradiian pidana. Apabila pencegahan kejahatan itu sendiri harus dijadikan tujuan utama darisistem peradilan pidana, maka sesuai dengan konsepsistem peradilan pidana sebagai tujuan bersama yang terpadu, hal itu harus benar-benar dipahami oieh subsistem-subsistem dalam sistem peradilan pidana sebagai

\footnotetext{
M. Yahya Harahap, 2002. Pembahasan Permasalahan dan Penerapan KUHAP, Sinar Grafika, Jakarta, hal 99

Andi Hamzah, 2002. Hukum Acara Pidana, Sinar Grafika, Jakarta, hal 118

Darwan Print, 2002. Hukum Acara Pidana dalam Praktek, Djambatan, Jakarta, hal 8

19 Chairul Huda, 1999, Kedudukan Subsistem Kepolisian dalam Sistem Peradilan Pidana, NO. 12 VOL 6. 1999. Yogyakarya
} 
tujuan bersama yang harus dicapai'secara bersama pula.

Menempatkan subsistem kepolisian tidak semata-mata sebagai penyeildik dan penyidik kejahatan, melainkan juga sebagai pejabat yang bertugas mencegah terjadinya kejahatan, menyebabkan subsistem kepolisian dihadapkan pada pekerjaan yang berada di luar tugasnya yang tradisional. Kepolisian juga bertugas untuk mengupayakan tercapainya tujuan (goal) masyarakat, yang menjadi kajian bidang kebijaksanaan kriminal. Kepolisian dipandang mempunyai fungsi preventif telah diakui sejak lama.

Van Voiienhoven pemah menyatakan bahwa, fungsi polisi itu menjalankan preventive rechtzorg yaitu memaksa penduduk suatu wilayah mentaati ketertiban hukum serta mengadakan penjagaan sebelumnya (preventif) supaya tertib masyarakat tetap terpelihara". ${ }^{20}$ Namun dikaitkannya fungsi preventif ini dengan pendekatan kebijakan (policy approach) merupakan konsep yang relatif baru. Adam Crawford berpendapat bahwa, pencegahan kejahatan ditempatkan sebagai tujuan utama kebijakan dan dlintegrasikan ke dalam tugas kepolisian mulai diperhatikan orang pada akhir tahun 1950-an, ${ }^{21}$ yang merekomendasikan diadakannya pelatihan khusus bagi aparat kepolisian sehingga menjadi ahli di bidang pencegahan kejahatan. Selain itu diperkenalkan pula partnership approach yang menekan keterlibatan organisasi di luar kepolisian untuk bersama-sama bertanggung jawab dalam pencegahan kejahatan.

Dari uraian diatas, terlihat bahwa subsistem kepolisian dewasa ini dituntut untuk dapat berfungsi tidak hanya berkenaan dengan tugas-tugasnya yang tradisional (menyidik kejahatan), tetapi lebih jauhsifatnya sehingga juga bertanggung jawab terhadap terwujudnya tujuan masyarakat yang telah ditetapkan, Dalam hal ini subsistem kepolisian tidak hanya sebagai gatekeepers sistem peradilan pidana, tetapi juga menjadi goal prevention officers. Hal ini mengharuskan pelaksanaan tugas kepolisian tidak semata-mata dilakukan sebagai reaksi atas terjadinya kejahatan, namun harus lebih banyak dilakukan secara proaktif mengendalikan kejahatan.

Dalam menanggulangi tindak pidana perjudian, Kepolisian sebagai salah satu komponen Sistem Peradilan Pidana di Indonesia, yang dilakukan adalah :

\section{Upaya Represif}

Upaya represif adalah upaya penanggulangan yakni segala upaya yang ditunjukan kepada seseorang yang telah menjadi jahat untukmenolongnya kembali kejalan yang benar, agar tidak mengulangi perbuatannya. ${ }^{22}$ yang berupa pemberian pidana terhadap pelaku kejahatan dapatlah dimasukkan agar orang yang bersangkutan dan masyarakat pada umumnya tidak melakukan tindak pidana. $^{23}$

Upaya ini dilakukan pada saat telah terjadi tindak pidana/kejahatan yang tindakan berupa penegakan hukum (law enforcement) dengan menjatuhkan hukuman. Upaya refresif adalah suatu upaya penanggulangan kejahatan secara konsepsional yang ditempuh setelah terjadinya kejahatan.

\footnotetext{
20 E. Utrecht.2010. Pengantar Hukum Administrasi Negara Indonesia. Penerbit dan Balai Buku Ichtiar, Jakarta, HIm. 60

21 Adam Crawford. 1997. The Local Governance of Crime. Oxford; Clarendon Press. Him. 26

22 Soedjono Dirdjosisworo, 1986. Penanggulangan Kejahatan (Crime Prevention), Alumni, Bandung, hlm. 155.

23 Arief, Barda Nawawi Arief. 2005. Beberapa Aspek Kebijakan Penegakan dan Pengembangan Hukum Pidana, Citra Aditya Bakti.Bandung. HIm. 23.
} 
Secara konkrit tindak itu disebut penyidikan dapat diperinci sebagai tindakan yang dilakukan oleh penyidik untuk mendapatkan keterangan tentang : ${ }^{24}$
a. Tindakpidanaapa yang telahdilakukan,
b. Kapan tindak pidana itu dilakukan,
c. Di mana tindak pidana itu dilakukan,
d. Dengan apa tindak pidana itu dilakukan,
e. Bagaimana tindak tidana itu dilakukan,
f. Mengapa tindak pidana itu dilakukan dan,
g. Siapa pembuatnya atau yang melakukan tindak pidana itu.

Rangkaian tindakan penyidikan adalah segala tindakan atas nama hukum yang dilakukan oleh Penyidik Polri, mulai dari pemanggilan, pemeriksaan, penangkapan, penahanan, penyitaan dan tindakan-tindakan lain yang diatur dalam ketentuan hukum, perundang-undangan yang berlaku hingga proses pneyidikan itu dinyatakan selesai. ${ }^{25}$

Penanganan tindak pidana perjudian oleh penyidik, dalam proses pelaksanakan berdasarkan KUHAP dan Peraturan Kapolri nomor 14 tahun 2012 tentang manajemen penyidikan tindak pidana. Penanganan tersangka di mulai dari adanya:
a. Adanya Laporan Polisi/Pengaduan
b. Melakukan penyergapan
c. Melakukan penyelidikan
d. Melakukan penyidikan :

1) Melakukan Penangkapan

2) Melakukan penggeledahan dan penyitaan

3) Melakukan Penahanan

e. Penyerahan berkas perkara kepada penuntut umum

Keseluruhan proses penyidikan yang telah dilakukan oleh Penyidik Polri tersebut kemudian akan dilanjutkan oleh Kejaksaan dalam hal mempersiapkan penuntutan yang akan diajukan dalam sidang pengadilan dan selanjutnya penjatuhan vonis kepada terdakwa yang kesemuanya itu berlangsung dalam suatu sistem peradilan pidana dalam rangka penegakan hukum pidana.Untuk tindak pidana perjudian proses penyidikan sama dengan tindak pidana pada umumnya sebagaimana tersebut di atas.

Dalam penanganan penyidikan tindak pidana perjudian pada umumnya terdapat beberapa hambatan yang dihadapai oleh penyidik dalam melakukan penyidikan.

Hal ini sesuai dengan teori kepastian hukum, Menurut Kelsenhukum adalah sebuah sistem norma. Norma adalah pernyataan yang menekankan aspek "seharusnya" atau das sollen, dengan menyertakan beberapa peraturan tentang apa yang harus dilakukan. Norma-norma adalah produk dan aksi manusia yang deliberatif. Undang-Undang yang berisi aturan-aturan yang bersifat umum menjadi pedoman bagi individu bertingkah laku dalam bermasyarakat, baik dalam hubungan dengan

24 Darwan Print, Op,cit, hal 8

25 Hartono, 2010. Penyidikan dan Penegakan Hukum Pidana melalui Pendekatan Hukum Progresif, Sinar Grafika, Jakarta, hal 116 
sesama individu maupun dalam hubungannya dengan masyarakat. Aturan-aturan itu menjadi batasan bagi masyarakat dalam membebani atau melakukan tindakan terhadap individu. Adanya aturan itu dan pelaksanaan aturan tersebut menimbulkan kepastian hukum. ${ }^{26}$

Aturan hukum berdasarkan Pasal 303 KUHP dan Pasal 303 bis KUHP Jo. Undang-Undang No. 7 Tahun 1974 tentang Penertiban Perjudian, dinyatakan bahwa semua bentuk perjudian adalah kejahatan. Selain itu, pernyataan tersebut diperkuat dengan adanya PP No. 9 Tahun 1981 tentang Pelaksanaan Undang-Undang No. 7 Tahun 1974 yang ditujukan kepada Pemerintah Pusat dan Pemerintah Daerah agar melarang atau mencabut izin perjudian dalam bentuk dan tujuan apapun. Semua peraturan tersebut dianggap sebagai perangkat hukum yang jelas untuk melarang kegiatan perjudian. Aturan ini memerintahkan kepada sistem peradilan pidana untuk melakukan penindakan apabila ada yang melakukan tindak pidana perjudian, Kepolisian sebagai subsistem peradilan pidana wajib melaksanakan tugasnya sesuai dengan ketentuan perundang-undangan yang berlaku demi terwujudnya kepastian hukum.

Hambatan dalam penyidikan tindak pidana perjudian yaitu kurangnya kepedulian masyarakat untuk bekerjasama dengan kepolisian dalam mengungkap tindak pidana perjudian. Penegakan hukum yang berasal dari masyarakat bertujuan untuk mencapai kedamaian dan rasa keamanan bersama di dalam masyarakat. Di sini peran masyarakat mempunyai pengaruh yang besar terhadap penangangan kasus tindak pidana khususnya perjudian, namun kurang kepedulian masyarakat untuk membantu aparat kepolisian dalam mengungkap tindak pidana perjudian begitu kurang. Pada kasus perjudian ini yang paling merasakan dampak perjudian adalah keluarga. Karena keluarga yang akan merasakan imbas dari perjudian apabila pelaku mengalami kekalahan dalam bermain judi. Masyarakat harusnya lebih peka dan ikut berpartisipasi untuk membantu aparat kepolisian dalam penanganan memberantas tindak pidana perjudian yang ada di sekitarnya. Kadang kala juga ada sebagian masryarakat yang resah akan adanya perjudian namun di sisi lain ada pula masyarakat yang acuh akan hal itu.

Hal ini sesuai dengan Teori Legal sistem atau teori sistem hukum dari Friedman menyatakan bahwa hukum harus dilihat sebagai suatu sistem. Lawrence M.Friedman dalam bukunya yang berjudul The Legal System: A Social Science Perspective, menyatakan bahwa setiap sistem hukum selalu mengandung tiga komponen, yaitu komponen struktur hukum (legal structure), substansi hukum (legal substance), dan budaya hukum (legal culture). A legal sistem in cctual operation is complex organism in which structure, substance, and culture interact."27 Artinya, sistem hukum dalam kenyataan sulit untuk dilaksanakan dalam berbagai organisasi yang akan mempengaruhi struktur, substansi, dan budaya. Friedman menulis "First many features of a working legal system can be called structural - the moving part, so to speak of the machine. Courts are simple and obvious example..." ${ }^{28}$ Artinya, salah satu bentuk bekerjanya sistem hukum dapat disebut sebagai struktur yang merupakan bagian mekanisme pengadilan. Pengadilan adalah contoh yang nyata dan sederhana. Komponen substansi hukum (legal

\footnotetext{
26 Peter Mahmud Marzuki, 2008. Pengantar Ilmu Hukum, Kencana, Jakarta, hlm.158.

27 Lawrence M. Friedman, 1969, The Legal System : A Social Science Perspective, Russel Sage Foundation, New York, hlm.16.

28 Lawrence M. Friedman, 1969, “On Legal Development” Dalam : Rutgers Law Rivies, Vol. 24. hlm.27.
} 
substance), Friedman menyatakan sebagai "...the actual product of the legal system". ${ }^{29}$ Menurutnya, pengertian substansi hukum meliputi aturan-aturan hukum, termasuk kaidah-kaidah hukum yang tidak tertulis. Komponen budaya hukum (legal culture). Sebelum dijelaskan lebih lanjut tentang budaya hukum, struktur dan substansi sering juga disebut sistemhukum. Budaya hukum oleh Friedman didefinisikan sebagai ..."attitudes and values that related to law and legal system, together with those attitudes and values effecting behavior related to law and its institutions, either positively or negatively. ${ }^{30}$ Artinya, sikap-skap dan nilai-nilai yang ada hubungannya dengan hukum atau sistem hukum, berikut sikap-sikap dan nilai-nilai yang memberi pengaruh kepada tingkah laku yang berkaitan dengan hukum dan institusi hukum, baik positif maupun negatif.

2. Upaya Preventif

Perjudian merupakan salah satu dari beberapa kejahatan sedangkan kejahatan itu sendiri sebagai perbuatan yang sangat merugikan, serta meresahkan masyarakat. Oleh karena itu tidak boleh dibiarkan begitu saja tumbuh dan berkembang dengan subur ditengah-tengah masyarakat.

Usaha pencegahan yang bersifat preventif ini dimaksudkan sebagai usaha pencegahan terhadap kemungkingan timbul serta meluasnya perjudian dalam masyarakat, jadi berusaha mencegah seseorang sebelum melakukan kejahatan tindak pidana perjudian, karena bila seseorang telah terjerumus melakukan suatu kejahatan akan sulit baginya untuk menjadi orang yang baik kembali, sebab kecenderungan untuk mengurangi perbuatan yang pernah dilakukan adalah sangat kecil. Sehingga usaha preventif ini sangat penting, bagaimana juga pencegahan masih jauh lebih baik daripada mengobati. Upaya pencegahan yang dapat dilakukan oleh Kepolisian adalah :

1. Melakukan penyuluhan hukum terhadap masyarakat. ${ }^{31}$

2. Membentuk tim untuk mengawasi tempat yang sering dijadikan sebagai tempat perjudian.

3. Memerkuat keyakinan agama bagi setiap individu karena semua agama melarang adanya perjudian

4. Melakukan patroli dan penjagaan atau pengawasan terhadap masyarakat.

\section{PENUTUP}

\section{Kesimpulan}

Tindak pidana perjudian merupakan suatu tindak pidana biasa namun memiliki dampak serius dalam masyarakat. Tindak pidana perjudian diatur dalam Pasal 303 KUHP dan Pasal 303 bis KUHP Jo. Undang-Undang No. 7 Tahun 1974 tentang Penertiban Perjudian, dinyatakan bahwa semua bentuk perjudian adalah kejahatan. Selain itu, pernyataan tersebut diperkuat dengan adanya PP No. 9 Tahun 1981 tentang Pelaksanaan Undang-Undang No. 7 Tahun 1974 yang ditujukan kepada Pemerintah Pusat dan Pemerintah Daerah agar melarang atau mencabut izin perjudian dalam bentuk dan tujuan apapun.

\footnotetext{
29 Ibid. HIm. 27

30 Ibid. Hlm. 28

31 Soedjono Dirdjosisworo, Op.cit. HIm. 155
} 
Dalam menanggulangi tindak pidana perjudian, Kepolisian yang merupakan subsistem peradilan pidana bertindak tidak hanya sebagai gatekeepers, tetapi juga menjadi goal prevention officers, yang dilakukan adalah :

1. Upaya Represif, Upaya ini dilakukan pada saat telah terjadi tindak pidana/kejahatan yang tindakan berupa penegakan hukum (law enforcement) dengan menjatuhkan hukuman. Sebagai subsistem peradilan pidana yang melaksanakan fungsi penyidikan, maka tindakan penyidikan dilakukan mulai dari pemanggilan, pemeriksaan, penangkapan, penahanan, penyitaan dan tindakan-tindakan lain yang diatur dalam ketentuan hukum, perundang-undangan yang berlaku hingga proses pneyidikan itu dinyatakan selesai.

2. Upaya Preventif, berupa upaya pencegahan terhadap kemungkingan timbul serta meluasnya perjudian dalam masyarakat. Upaya pencegahan yang dapat dilakukan oleh Kepolisian adalah : Melakukan penyuluhan hukum terhadap masyarakat, Membentuk tim untuk mengawasi tempat yang sering dijadikan sebagai tempat perjudian, Memerkuat keyakinan agama bagi setiap individu karena semua agama melarang adanya perjudian, Melakukan patroli dan penjagaan atau pengawasan terhadap masyarakat.

\section{Saran}

1. Kepolisian sebagai gateskeeper yang menentukan suatu tindak pidana dapat dilimpahkan ke tahap selanjutnya, maka harus lebih transparan lagi terkait pelimpahan perkara tindak pidana perjudian ke Kejaksaan. Disini perlu adanya keterbukaan adanya perkara tidak sampai diteruskan ke Kejaksaan. Jika hal ini terus dibiarkan maka pelaku yang perkaranya tidak sampai diteruskan ke Kejaksaan maupun masyarakat yang mengetahui hal tersebut menjadi tidak takut lagi akan sanksi dari perjudian. Sebaliknya jika Kepolisian tegas dan berani dalam melimpahkan seluruh perkara yang ditanganinya sesuai proses hukum yang berlaku maka pelaku dan masyarakat pada umumnya terdorong untuk tidak melakukan tindak pidana perjudian;

2. Untuk menanggulangi tindak pidana perjudian, tidak hanya dengan mengandalkan peran Kepolisian, tetapi juga perlu adanya partisipasi dari masyarakat. Masyarakat hendaknya tidak tertutup dan bersikap masa bodoh menanggapi terjadinya tindak pidana perjudian. Masyarakat harus lebih terbuka dalam memberikan informasi serta laporan kepada Kepolisian terkait tindak pidana perjudian yang terjadi di sekitar wilayah tempat tinggalnya, sehingga Kepolisian dapat segera bertindak guna meminimalisir terjadinya tindak pidana perjudian demi terciptanya lingkungan masyarakat yang aman, damai dan tentram.

\section{DAFTAR PUSTAKA}

Adam Crawford. 1997. The Local Governance of Crime. Oxford; Clarendon Press.

Ali Wisnubroto, 2002. Praktek Peradilan Pidana (Proses Persidangan Perkara Pidana), PT. Galaxy Puspa Mega, Jakarta.

Andi Hamzah, 2002. Hukum Acara Pidana, Sinar Grafika, Jakarta.

Anton Tabah, 1991, Menatap Dengan Mata Hati Polisi Indonesia, PT Gramedia Pustaka Utama, Jakarta. 
Arief, Barda Nawawi Arief. 2005. Beberapa Aspek Kebijakan Penegakan dan Pengembangan Hukum Pidana, Citra Aditya Bakti. Bandung.

Darwan Print, 2002. Hukum Acara Pidana dalam Praktek, Djambatan, Jakarta.

E. Utrecht.2010. Pengantar Hukum Administrasi Negara Indonesia. Cet VI, Penerbit dan Balai Buku Ichtiar, Jakarta.

Hartono, 2010. Penyidikan dan Penegakan Hukum Pidana melalui Pendekatan Hukum Progresif, Sinar Grafika, Jakarta.

J.W. Lapatra, 1078. Analyzing the Criminal Justice Systems, Lexinton Books. Massachusetts.

John Baldwin dan A. Keith Bottomley(ed). 1978. Criminal; Selected Readings. Martin Robertson. London.

Kartono, Kartini. 2011. Patologi Sosial Jilid 1. Rajagrafindo Persada, Jakarta.

Lawrence M. Friedman, 1969, The Legal System : A Social Science Perspective, Russel Sage Foundation, New York.

M. Yahya Harahap, 2002. Pembahasan Permasalahan dan Penerapan KUHAP, Sinar Grafika, Jakarta.

Mardjono Reksodiputro, 1993. Sistem Peradilan Pidana Indonesia (Melihat Kepada Kejahatan Dan Penegakan Hukum Dalam Batas-Batas Toleransi), Fakultas Hukum Unversitas Indonesia, Jakarta,

Mohammad Kemal Darmawan dan Mohammad Irvan Oli'i, 2015. Sosiologi Peradilan Pidana, Fakultas IImu Sosial dan IImu Politik Universitas Indonesia bekerjasama dengan Yayasan Pustaka Onor Indonesia, Jakarta.

Momo Kelana, 1994, Hukum Kepolisian, PTIK/Gramedia, Jakarta.

Peter Mahmud Marzuki, 2008. Pengantar Ilmu Hukum, Kencana, Jakarta.

Romli Atmasasmita, 2002. Sistem Peradilan Pidana ; Perspektif Eksistensialisme dan bilisionisme, Rineka Cipta, Bandung.

Soedjono Dirdjosisworo, 1986. Penanggulangan Kejahatan (Crime Prevention), Alumni, Bandung.

Chairul Huda, 1999, Kedudukan Subsistem Kepolisian dalam Sistem Peradilan Pidana, NO. 12 VOL 6. 1999. Yogyakarta

Karolina Sitepu, 2015. Pemberantasan dan Penanggulangan Tindak Pidana Perjudian Togel di Wilayah Hukum Polresta Medan, Jurnal Ilmiah “RESEARCH SAINS” Vol. 1 No. 1 Januari 2015. Medan.

Lawrence M. Friedman, 1969, “On Legal Development” Dalam : Rutgers Law Rivies, Vol. 24.

Zulkarnaen Koto, 2011. Terobosan Hukum dalam Penyederhanaan Proses Peradilan Pidana, Jurnal Studi Kepolisian, STIK, Jakarta.

http://darpawan.wordpress.com/2009/12/14/menemukan-keadilan-dalam-penjatuhan-pidana/ 